\title{
Alveolar concentration of nitric oxide predicts pulmonary function deterioration in scleroderma
}

\author{
Kiet Phong Tiev, ${ }^{1}$ Thong Hua-Huy, ${ }^{2}$ Adrien Kettaneh, ${ }^{1}$ Yannick Allanore, ${ }^{3}$ \\ Nhat-Nam Le-Dong, ${ }^{2}$ Sy Duong-Quy, ${ }^{2}$ Jean Cabane, ${ }^{1}$ Anh Tuan Dinh-Xuan ${ }^{2}$
}

'Department of Internal Medicine, University Paris Pierre et Marie Curie, Saint Antoine Hospital, Paris, France ${ }^{2}$ Department of Physiology, University Paris Descartes, Cochin Hospital, Paris, France ${ }^{3}$ Department of Rheumatology A, University Paris Descartes, Cochin Hospital, Paris, France

\section{Correspondence to Professor Anh Tuan Dinh-Xuan, Department of Physiology, University Paris Descartes, Cochin Hospital, 27 rue du faubourg Saint-Jacques, 75679 Paris cedex 14, France; anh-tuan.dinh-xuan@cch.aphp. fr}

Received 21 May 2011 Accepted 22 September 2011 Published Online First 24 October 2011
ABSTRACT

Background Respiratory failure is a life-threatening and unpredictable complication of systemic sclerosis (SSc). A study was undertaken to assess the value of alveolar nitric oxide (NO) in predicting the risk of lung function deterioration leading to respiratory failure or death in patients with SSc.

Methods 105 patients with SSc were enrolled in this prospective cohort and were followed longitudinally over a 3-year period during which the risk of occurrence of deleterious events was analysed according to alveolar concentration $\left(\mathrm{C}_{\mathrm{A}} \mathrm{NO}\right)$, conducting airway output $\left(\mathrm{J}^{\prime}{ }_{\text {aw }} \mathrm{NO}\right)$ and fractional concentration $\left(\mathrm{F}_{\mathrm{N} \mathrm{NO}_{0.05}}\right)$ of exhaled $\mathrm{NO}$ measured at inclusion. Comparison was made between each NO parameter to predict the occurrence of deleterious events, defined as a $10 \%$ decrease in total lung capacity or forced vital capacity from baseline, or death.

Results The area under the receiver operating characteristic curve of $\mathrm{C}_{\mathrm{A}} \mathrm{NO}$ to predict the occurrence of the combined events was $0.84(95 \% \mathrm{Cl} 0.76$ to 0.92 ; $p<0.001)$, which was significantly higher than those of $\mathrm{J}^{\prime}{ }_{\text {aw NO }}$ and $\mathrm{F}_{\mathrm{E}} \mathrm{NO}_{0.05}(\mathrm{p}<0.001)$. A cut-off of $\mathrm{C}_{\mathrm{A}} \mathrm{NO}$ of $5.3 \mathrm{ppb}$ had a sensitivity of $88 \%$ and a specificity of $62 \%$ for the prediction of the occurrence of combined events during follow-up, and was validated in an independent cohort of patients with SSc. Combined events occurred more frequently in patients whose $\mathrm{C}_{\mathrm{A}} \mathrm{NO}$ was $>5.3 \mathrm{ppb}$. The adjusted $\mathrm{HR}$ for patients with $\mathrm{C}_{\mathrm{A}} \mathrm{NO}>5.3 \mathrm{ppb}$ was 6.06 (95\% Cl 2.36 to $15.53 ; p<0.001)$. $\mathrm{C}_{\mathrm{A} N \mathrm{~N}}$ accurately predicted the occurrence of combined events irrespective of forced vital capacity values or the presence of interstitial lung disease at baseline.

Conclusions Increased $\mathrm{C}_{\mathrm{A}}$ NO accurately identifies patients with SSc with a high risk of developing lung function deterioration and may help to initiate early appropriate treatment.

\section{INTRODUCTION}

Systemic sclerosis (SSc) is a connective tissue disease characterised by immune activation, vascular damage and fibrosis of various organs including the skin, gastrointestinal tract, kidneys and lungs. ${ }^{1}$ Interstitial lung disease (ILD), an unpredictable and life-threatening condition that occurs in more than half of patients, ${ }^{2}$ is the main cause of death in SSc. ${ }^{3}$ ILD related to SSc (SSc-ILD) gradually and irreversibly decreases lung volumes, impairs lung gas exchanges and reduces walking distance. As a result, quality of life and daily activities are markedly impaired in most patients, and death eventually

\section{Key messages}

What is the key question?

- Identification of progressive form of scleroderma lung disease by nitric oxide (NO) exhaled marker

What is the bottom line?

- Elevated Alveolar concentration of $\mathrm{NO}\left(\mathrm{C}_{\mathrm{A}} \mathrm{NO}\right)$ is valuable marker in predicting the risk of subsequent lung function deterioration or death in patients with scleroderma.

Why read on?

- $\mathrm{C}_{\mathrm{A}} \mathrm{NO}$ cut-off is validated, as predictive marker of progressive form of scleroderma lung disease in an independent cohort, which allows clinician initiating appropriate treatment in early phase of disease.

occurs in those with the most severe form of the disease. ${ }^{2}{ }^{4}$ Annual pulmonary function tests (PFTs) are recommended to detect lung function worsening, which is considered a critical turning point in the natural course of SSc-ILD. ${ }^{5}$

The current hypothesis regarding the pathogenesis of SSc-ILD suggests the occurrence(s) of pulmonary injuries initiated by unknown factor(s) followed by cryptic but sustained and incompletely resolved autoimmune alveolitis that eventually results in pulmonary fibrosis. ${ }^{6}$ Immunosuppressive agents only have minor beneficial effects to slow down the rate of lung function decline of patients with SSc in whom it is impossible to restore lung volumes to normal. ${ }^{7} 8$ There is an urgent need to find biomarkers capable of identifying patients whose lung function might deteriorate dramatically and rapidly and who will consequently benefit from timely and effective treatment.

Alveolar inflammation, which releases proinflammatory cytokines into the bloodstream and nitric oxide (NO) into the exhaled air, ${ }^{910}$ is the main monitoring option for ILD. NO, a key intercellular and intracellular mediator, is both a powerful endogenous vasodilator and a highly reactive biomarker of inflammation. In patients with SSc, inducible NO synthase is abundantly expressed in inflamed lung tissue, thus favouring excessive synthesis of $\mathrm{NO}$ and its resulting increased concentration in the exhaled air of patients with SSc-ILD. ${ }^{11}$ Using a partitioned exhaled NO model ${ }^{12}$ that splits 
fractional exhaled $\mathrm{NO}\left(\mathrm{F}_{\mathrm{E}} \mathrm{NO}\right)$ into airway conducting maximal $\mathrm{NO}$ output $\left(\mathrm{J}^{\prime}{ }_{\mathrm{aw}} \mathrm{NO}\right)$ and alveolar concentration of $\mathrm{NO}\left(\mathrm{C}_{\mathrm{A}} \mathrm{NO}\right)-$ reflecting the underlying bronchi and alveolar inflammation-we and others ${ }^{13}$ have previously shown that increased $\mathrm{C}_{\mathrm{A}}$ NO levels are related to the importance of SSc-ILD in vivo ${ }^{14}$ and the ability of the serum from patients with SSc to induce fibrosis in vitro. ${ }^{15}$ However, the relationship between exhaled $\mathrm{NO}$ output and subsequent occurrence of lung function deterioration or death has not yet been studied in patients with SSc. We hypothesised that partitioned measurement of exhaled $\mathrm{NO}$, enabling assessment of fractioned exhaled $\mathrm{NO}$ at $50 \mathrm{ml} / \mathrm{s}$ of outflow $\left(\mathrm{F}_{\mathrm{E}} \mathrm{NO}_{0.05}\right)$ and calculation of $\mathrm{J}^{\prime}$ aw $\mathrm{NO}$ and $\mathrm{C}_{\mathrm{A}} \mathrm{NO}$, might help to estimate the risk of developing subsequent lung function deterioration or death in patients with SSc. A prospective cohort study was therefore

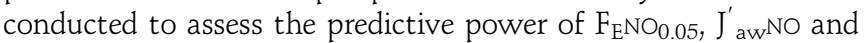
$\mathrm{C}_{\mathrm{A} N O}$ to predict lung function deterioration or death in patients with SSc.

\section{METHODS \\ Study design}

Enrolment was conducted from November 2004 to May 2007 in the Department of Internal Medicine, Hospital Saint Antoine, Paris, France, and the follow-up of this time to event driven study ended in May 2010.

\section{Inclusion criteria}

Patients were considered for inclusion if they were aged $>18$ years and had a diagnosis of $\mathrm{SSc}^{16}$ with diffuse or limited forms, ${ }^{17}$ the presence of ILD diagnosed by chest highresolution computed tomography (HRCT) and the presence of pulmonary hypertension $(\mathrm{PH})$ ascertained by right heart catheterisation (RHC), irrespective of the level of forced vital capacity (FVC) and lung transfer factor for carbon monoxide (TLCO). Patients treated with corticosteroids and immunosuppressive agents were also eligible and recorded as presence of immunosuppressive therapy.

\section{Exclusion criteria}

Exclusion criteria were the presence of recent airway upper tract infection or pneumonia in the previous 3 months, the presence of lung cancer, asthma, allergic rhinitis, chronic obstructive pulmonary disease and treatment by NO donors. Patients who were unable to perform partitioned exhaled $\mathrm{NO}$ were also excluded.

\section{Study design}

At the start of the study, demographic data, duration of disease (delay between first symptom attributable to SSc and inclusion date), subset of SSc and history of smoking were recorded. All patients underwent extended NO analysis, PFTs, chest HRCT scanning and an echocardiogram. PFTs were routinely performed with a standard methodology and quality controls according to the American Thoracic Society and the European Respiratory Society (ATS/ERS) recommendations. ${ }^{18}$ ILD related to SSc was determined by the presence of reticular or ground glass changes extending at least to the venous confluence on the chest HRCT scan according to the ATS/ERS consensus ${ }^{19}$ and recorded as presence of ILD. Systolic pulmonary artery pressure was first estimated by echocardiography. All patients with $>40 \mathrm{~mm} \mathrm{Hg}$ subsequently underwent RHC. PH was confirmed as mean pulmonary artery $\geq 25 \mathrm{~mm} \mathrm{Hg}$ according to ATS/ERS consensus $^{20}$ and recorded as presence of $\mathrm{PH}$.

\section{Partitioned exhaled NO measurement}

Briefly, fractional exhaled $\mathrm{NO}\left(\mathrm{F}_{\mathrm{E}} \mathrm{NO}\right)$ was measured using a chemiluminescent analyser (EndoNO 8000, SERES, Aix-enProvence, France) according to the ATS/ERS recommendations. ${ }^{21}$ After a full inspiration of room air, the subject exhaled against a positive pressure to generate exhalation flow rates $\left(V_{\mathrm{E}}^{\prime}\right)$ of $50,100,150$ and $200 \mathrm{ml} / \mathrm{s}$. For each $\mathrm{V}_{\mathrm{E}}^{\prime}$, the elimination rate of $\mathrm{NO}\left(\mathrm{V}^{\prime}{ }_{\mathrm{NO}}\right)$ was calculated as a function of $\mathrm{V}_{\mathrm{E}}^{\prime}\left(\mathrm{V}^{\prime}{ }_{\mathrm{NO}}=\mathrm{V}_{\mathrm{E}}^{\prime} \times\right.$ $\left.\mathrm{F}_{\mathrm{E}} \mathrm{NO}\right)$. At a flow rate of $>50 \mathrm{ml} / \mathrm{s}$, this relationship is linear and can be expressed as $\mathrm{V}^{\prime}{ }_{\mathrm{NO}}=\mathrm{V}_{\mathrm{E}}^{\prime} \times \mathrm{F}_{\mathrm{E} N O}=\mathrm{C}_{\mathrm{A} N O} \times \mathrm{V}_{\mathrm{E}}^{\prime}+$ $\mathrm{J}^{\prime}{ }_{\mathrm{aw}} \mathrm{NO}^{12}{ }^{22} \mathrm{~J}_{\mathrm{aw}}^{\prime} \mathrm{NO}$ is the maximal conducting airway flux of $\mathrm{NO}$.

\section{Endpoint}

The endpoint was the occurrence of combined deleterious events, defined as a $10 \%$ decrease in total lung capacity or FVC from baseline, or death. ${ }^{2}$ Survival status was obtained from visits and telephone interviews. Patients not seen within 3 months were called to confirm their living status. Patients were evaluated by PFTs, chest HRCT and echocardiography annually (or earlier in an additional visit if symptoms required).

\section{Confirmation study in an independent population}

To validate the prediction power of extended $\mathrm{NO}$ analysis for lung function deterioration or death in SSc, we performed a confirmation study involving patients with SSc enrolled in the same inclusion protocol from September 2006 to September 2007 in the Department of Rheumatology (Cochin Hospital, Paris, France) and followed up over 3 years to determine the occurrence of combined events.

\section{Statistical analysis}

We first assessed the diagnostic performance of $\mathrm{C}_{\mathrm{A}} \mathrm{NO}, \mathrm{J}^{\prime}$ aw $\mathrm{NO}$ and $\mathrm{F}_{\mathrm{E}^{N O}} \mathrm{O}_{0.05}$ for identifying patients with $\mathrm{SSc}$ who were going to have subsequent worsening of their lung disease or were going to die within the 3 years after inclusion (positive if combined events occurred within 3 years of follow-up and negative if combined events did not occur) using receiver operating characteristic curves (ROC) analysis. We compared their performances with each other using the method described by DeLong et al. ${ }^{23}$

We next determined the threshold of the best parameter that was able to predict the subsequent occurrence of combined events in the 3 years after inclusion based on Youden's index (maximal sum of sensitivity + specificity). To ensure the relevance of the predicted cut-off of the extended $\mathrm{NO}$ analysis for subsequent lung function deterioration or death within 3 years after inclusion, a confirmation study was performed in an independent cohort of patients with SSc from Cochin Hospital (figure 1). Continuous and categorical variables were presented as mean $\pm \mathrm{SD}$ and percentages and were compared between groups by two-sample $t$ tests and $\chi^{2}$ tests, respectively.

We divided the studied population into two groups according to the best threshold to predict the subsequent occurrence of

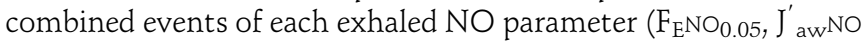
and $\mathrm{C}_{\mathrm{A} N \mathrm{~N}}$ ) at baseline. To estimate the predictive value of exhaled NO parameters on lung function outcomes during the whole follow-up period, cumulative risks were computed by Kaplan-Meier analysis. ORs for lung function deterioration over time according to $\mathrm{NO}$ measurements were estimated by the Cox proportional hazard model. For all parameters, the conformity with the proportional hazards assumption was tested by linear regression of Schoenfeld residuals on the time variable in 
Figure 1 Details of enrolment and flow of patients through study. $\mathrm{C}_{\mathrm{A}} \mathrm{NO}$, alveolar concentration of nitric oxide.

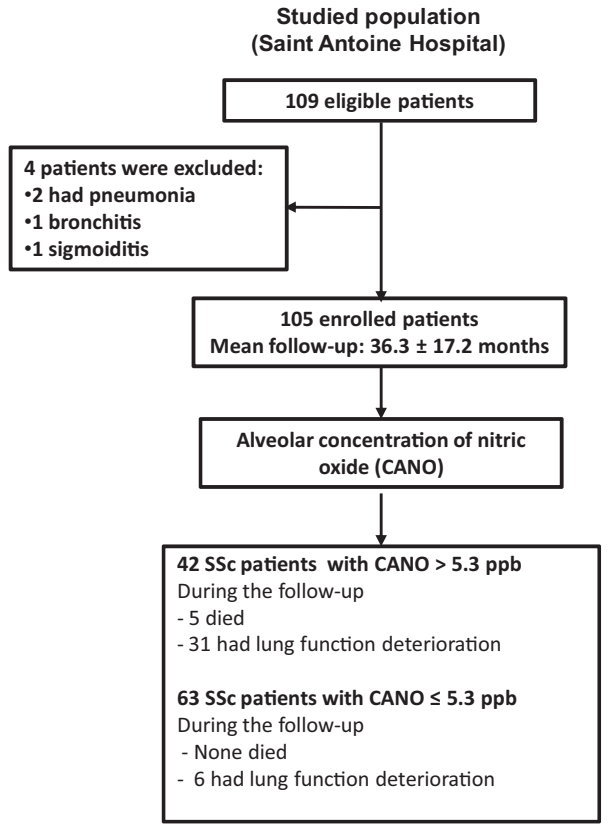

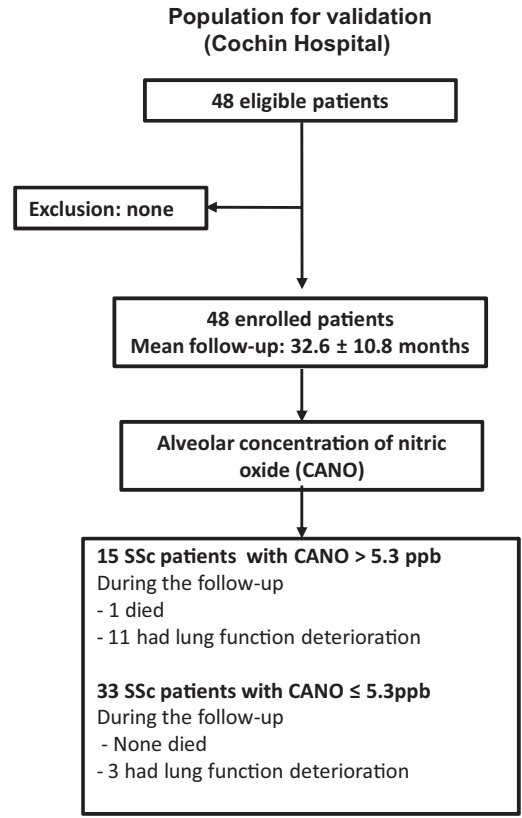

observations with event $=1$. For categorical parameters, the conformity with the proportional hazards assumption was verified graphically in addition to construction of Kaplan-Meier curves. Only parameters fulfilling the proportional hazards assumption were used in the Cox analysis.

We first conducted unadjusted Cox analyses according to each baseline characteristic separately. In these models, NO variables were set as continuous variables. For any NO variable significant in this procedure, an additional unadjusted model was performed with a categorical two-level NO variable according to the corresponding optimal threshold in ROC curves. A multivariable Cox model further adjusted the categorical $\mathrm{NO}$ variable for age, FVC, TLCO and duration of disease as continuous variables and gender, smoking status, form of disease, the presence of ILD, PH diagnosed by RHC and immunosuppressive therapy as categorical variables.

We then assessed the relationship between change in FVC and variation of exhaled $\mathrm{NO}$ parameters between baseline and the last visit using a linear regression model. All tests were two-sided with a significance level of $5 \%$. All analyses were performed with STATA Statistical Software Release 10 (Stata Corporation, College Station, Texas, USA).

\section{RESULTS}

\section{Baseline characteristics of population}

One hundred and nine patients with SSc were eligible for this prospective study. Four patients were excluded (two with pneumonia, one with bronchitis and one with sigmoiditis; figure 1). One hundred and five patients were therefore consecutively included in the study (table 1).

The mean age of the patients at inclusion was $54.8 \pm 12.9$ years and $13(12.4 \%)$ were men. One-third of the patients had the diffuse form of SSc and half of the patients had ILD. Seventeen of the 105 patients $(16.2 \%)$ took immunosuppressive agents (cyclophosphamide, $\mathrm{n}=1$; mycophenolate mofetil, $\mathrm{n}=1$; corticosteroids, $n=15$ ). After a mean follow-up of $36.3 \pm 17.2$ months, five patients with SSc died from end-stage lung fibrosis, 34 had lung function deterioration, 66 were censored and no patient was lost to follow-up. The composite events, defined as death or a decrease of $10 \%$ in total lung capacity or FVC, occurred in 39 patients (37\%). Three new cases of ILD were diagnosed by chest HRCT during the follow-up period.

A comparison of the characteristics of the studied population and those of the population used for external validation is shown in table 1 and figure 1 . At baseline the mean duration of disease and the rate of smokers were higher in the study group

Table 1 Baseline characteristics of studied population and population for external validation of $\mathrm{C}_{\mathrm{A}} \mathrm{No}$ threshold

\begin{tabular}{|c|c|c|c|}
\hline & $\begin{array}{l}\text { All SSc } \\
\text { patients } \\
(\mathrm{n}=105)\end{array}$ & $\begin{array}{l}\text { SSc population } \\
\text { for validation } \\
(\mathrm{n}=48)\end{array}$ & p Value \\
\hline \multicolumn{4}{|l|}{ Demographics } \\
\hline $\begin{array}{l}\text { Age, } \\
\text { years }\end{array}$ & $54.8 \pm 12.9$ & $56.1 \pm 12.7$ & 0.564 \\
\hline Men & $13(12.4)$ & $10(20.8)$ & 0.174 \\
\hline \multicolumn{4}{|l|}{ Smoking status } \\
\hline Never smoking & $83(79.0)$ & 47 (97.9) & 0.005 \\
\hline Ex-smoker & $12(10.5)$ & $0(0)$ & 0.030 \\
\hline Current smoker & $10(9.5)$ & $1(2.1)$ & 0.181 \\
\hline \multicolumn{4}{|l|}{ Systemic sclerosis } \\
\hline Duration of disease (years) & $11.4 \pm 11.6$ & $7.9 \pm 5.8$ & 0.014 \\
\hline Diffuse SSc & $35(33.3)$ & $18(37.5)$ & 0.615 \\
\hline \multicolumn{4}{|l|}{ Lung disease } \\
\hline Presence of ILD & $51(48.6)$ & $23(47.9)$ & 0.940 \\
\hline FVC $(\%)^{*}$ & $97 \pm 23$ & $98 \pm 22$ & 0.809 \\
\hline TLCo $(\%)^{*}$ & $63 \pm 17$ & $61 \pm 19$ & 0.583 \\
\hline $\begin{array}{l}\text { Pulmonary } \\
\text { hypertension } \dagger\end{array}$ & $6(5.7)$ & $1(2.1)$ & 0.564 \\
\hline \multicolumn{4}{|l|}{ Treatment } \\
\hline $\begin{array}{l}\text { Immunosuppressive } \\
\text { therapy }\end{array}$ & $17(16.2)$ & $13(27.1)$ & 0.105 \\
\hline \multicolumn{4}{|l|}{ Partitioned exhaled nitric oxide } \\
\hline $\mathrm{C}_{\mathrm{A}} \mathrm{No}(\mathrm{ppb})$ & $6.9 \pm 5.5$ & $7.2 \pm 5.7$ & 0.814 \\
\hline $\mathrm{J}_{\text {awNO }}^{\prime}(\mathrm{ml} / \mathrm{min})$ & $29.0 \pm 20.4$ & $30.8 \pm 10.3$ & 0.695 \\
\hline $\mathrm{F}_{\mathrm{E}} \mathrm{NO}_{0.05}(\mathrm{ppb})$ & $16.6 \pm 12.1$ & $17.4 \pm 10.3$ & 0.663 \\
\hline \multicolumn{4}{|c|}{ 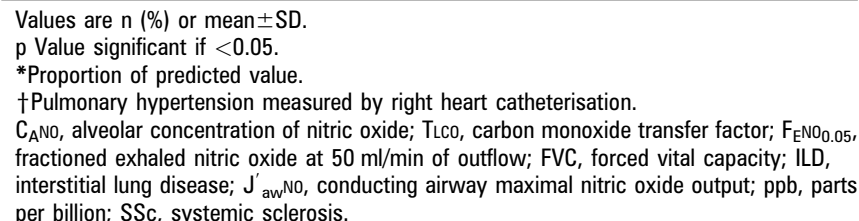 } \\
\hline
\end{tabular}


Figure 2 Performance of alveolar concentration of nitric oxide $\left(\mathrm{C}_{\mathrm{A}} \mathrm{NO}\right)$, conducting airways output of nitric oxide $\left(\mathrm{J}_{\mathrm{aw}}^{\prime} \mathrm{NO}\right)$ and fractional exhaled concentration of nitric oxide at $50 \mathrm{ml} /$ min of outflow $\left(\mathrm{F}_{\mathrm{E}} \mathrm{NO}_{0.05}\right)$ for predicting lung function deterioration or death 3 years after inclusion in the study. The black line represents the receiver operating characteristic (ROC) curve of $\mathrm{C}_{\mathrm{A}} \mathrm{NO}$ with an area under the curve of $0.84(95 \% \mathrm{Cl} 0.76$ to $0.92 ; \mathrm{p}<0.001)$, the grey line represents the ROC curve of $\mathrm{F}_{\mathrm{E}} \mathrm{NO}_{0.05}$ with an area under the curve of 0.64 (95\% Cl 0.53 to 0.75 ; $\mathrm{p}=0.007$ ) and the dotted grey line represents $\mathrm{J}_{\text {aw }}$ NO with an area under the curve of 0.52 (95\% Cl 0.40 to 0.64 ; $\mathrm{p}=0.194)$. The difference between the three areas under the ROC curves was statistically significantly $(\mathrm{p}<0.001)$.

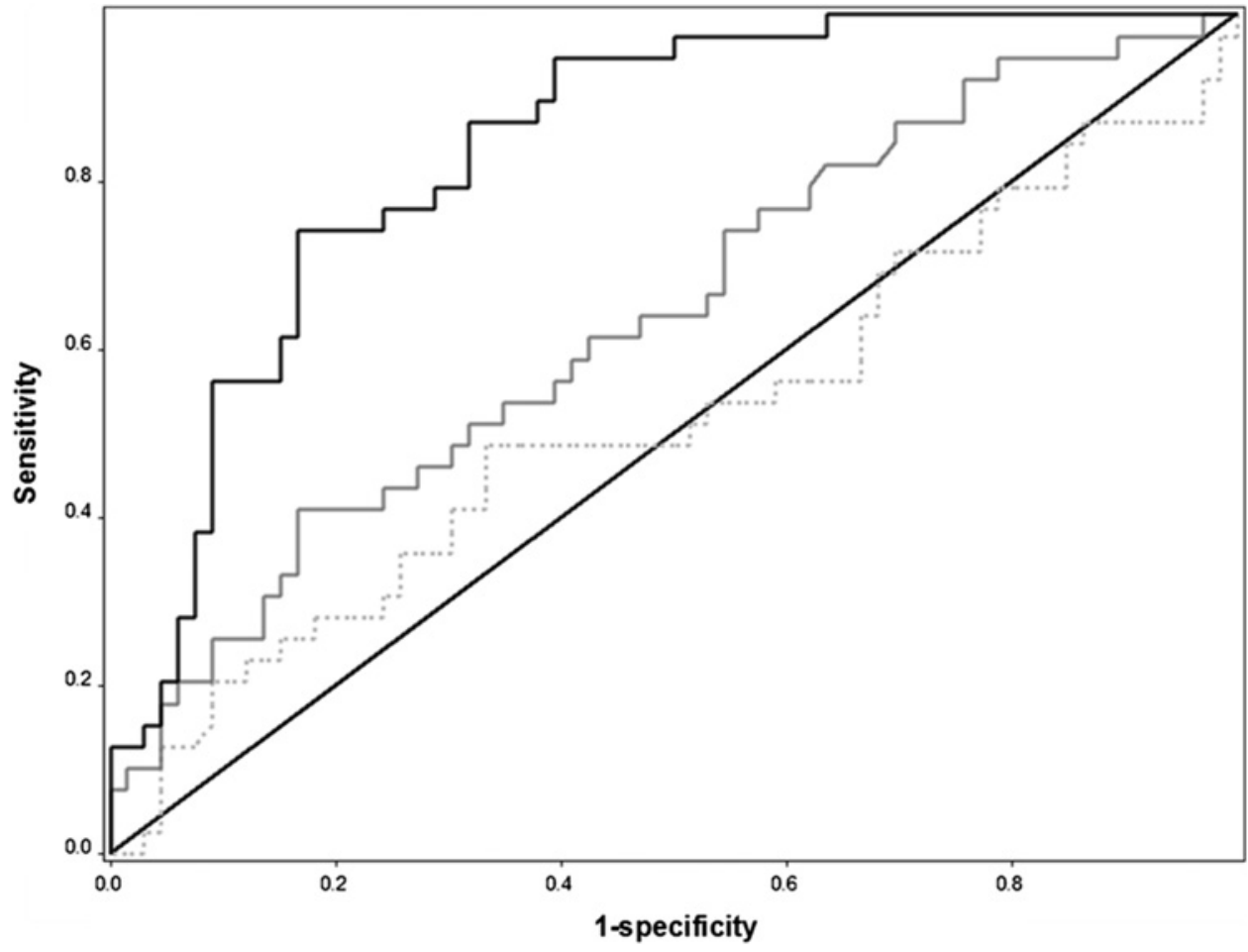

of patients than in the external validation group of patients with SSc.

Prediction power of $\mathrm{F}_{\mathrm{E}^{\mathrm{NO}}} \mathrm{O}_{0.05}, \mathrm{~J}_{\text {aw }}^{\prime}$ NO and $\mathrm{C}_{\mathrm{A}} \mathrm{NO}$ for occurrence of combined events during 3 years after start of study

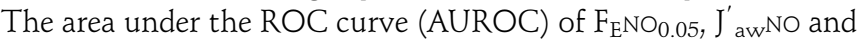
$\mathrm{C}_{\mathrm{A}} \mathrm{NO}$ for prediction of occurrence of combined events during the 3 years after inclusion in the study were significantly different from one another $(\mathrm{p}<0.001$, figure 2$)$. The AUROC of $\mathrm{C}_{\mathrm{ANO}}$ for predicting the occurrence of combined events was 0.84 (95\% CI 0.76 to $0.92 ; \mathrm{p}<0.001)$ while the AUROC of $\mathrm{F}_{\mathrm{E} N O_{0.05}}$ was significantly lower $(0.64,95 \%$ CI 0.53 to $0.75 ; p=0.007)$. In contrast, $\mathrm{J}^{\prime}$ aw $\mathrm{NO}$ had no value for predicting the occurrence of combined events (AUROC $=0.52,95 \%$ CI 0.40 to $0.64 ; \mathrm{p}=0.194$ ). Moreover, the AUROC curve of $\mathrm{C}_{\mathrm{A}} \mathrm{NO}$ for predicting the occurrence of combined events during the 3 years after inclusion in patients from Cochin Hospital (0.83 (95\% CI 0.75 to 0.92); $\mathrm{p}<0.001)$ was comparable with that in patients from Saint Antoine Hospital. Among the exhaled $\mathrm{NO}$ parameters, $\mathrm{C}_{\mathrm{A}} \mathrm{NO}$ had the best performance power. We therefore determined the best cut-off of $\mathrm{C}_{\mathrm{A}} \mathrm{NO}$ for predicting the combined events during the 3 years after inclusion and compared the risk of developing worsening lung function or dying during the whole follow-up with patients with SSc with $\mathrm{C}_{\mathrm{A}}$ No higher than this latter cut-off and the remaining patients.

\section{Threshold of $\mathrm{C}_{\mathrm{A} \text { NO }}$ to identify patients with SSc at risk of deterioration of lung disease or death during the $\mathbf{3}$ years after inclusion}

The best cut-off of $\mathrm{C}_{\mathrm{A}} \mathrm{NO}$ for identifying deterioration in lung disease within 3 years was 5.3 ppb (95\% CI 3.4 to 7.4 ). The sensitivity (Se), specificity ( $\mathrm{Sp}$ ), positive and negative predictive values (PPV and NPV) were 0.88 (95\% CI 0.74 to 0.96$), 0.62$ (95\% CI 0.49 to 0.74$), 0.61$ (95\% CI 0.47 to 0.73 ) and 0.89 (95\% CI 0.75 to 0.96$)$, respectively compared with values of Se, Sp, PPV and NPV were 0.80 (95\% CI 0.52 to 0.96$), 0.61$ (95\% CI 0.42 to 0.77 ), 0.50 (95\% CI 0.27 to 0.69 ) and 0.87 (95\% CI 0.66 to 0.80 ), respectively, in the validation population. Se and Sp obtained in the validation study with $5.3 \mathrm{ppb}$ as cut-off were very close to those observed in the studied population, confirming the robustness of $\mathrm{C}_{\mathrm{A}} \mathrm{NO}$ as a predictor of deteriorating lung function or death occurring during the 3 years after inclusion. The $\mathrm{C}_{\mathrm{A}} \mathrm{NO}$ threshold with $90 \%$ specificity for identifying subsequent deterioration of lung disease within 3 years was $8.5 \mathrm{ppb}$. Se and $\mathrm{Sp}$

Table 2 Unadjusted Cox HRs for deterioration in lung function over time according to each baseline characteristic

\begin{tabular}{|c|c|c|}
\hline & $\begin{array}{l}\text { HR } \\
(95 \% \mathrm{CI})\end{array}$ & p Value \\
\hline \multicolumn{3}{|l|}{ Demographics } \\
\hline Age (as continuous variable, per year) & $1.02(0.99$ to 1.05$)$ & 0.142 \\
\hline Men* & $1.96(0.90$ to 4.26$)$ & 0.089 \\
\hline History of smoking* & $0.70(0.27$ to 1.79$)$ & 0.451 \\
\hline \multicolumn{3}{|l|}{ Systemic sclerosis } \\
\hline Diffuse form of SSc* & $2.56(1.35$ to 4.76$)$ & 0.011 \\
\hline $\begin{array}{l}\text { Duration of disease } \\
\text { (as continuous variable, per year) }\end{array}$ & $1.00(0.97$ to 1.03$)$ & 0.843 \\
\hline \multicolumn{3}{|l|}{ Lung disease } \\
\hline Presence of ILD* & $3.52(1.75$ to 7.08$)$ & 0.001 \\
\hline TLCo (as continuous variable, per $\% \dagger$ ) & $0.96(0.94$ to 0.98$)$ & $<0.001$ \\
\hline FVC (as continuous variable, per $\% \dagger$ ) & $0.98(0.96$ to 0.99$)$ & 0.005 \\
\hline Presence of pulmonary hypertension* & $1.32(0.40$ to 4.28$)$ & 0.651 \\
\hline \multicolumn{3}{|l|}{ Treatment } \\
\hline Immunosuppressive treatment* & $2.32(1.15$ to 4.67$)$ & 0.024 \\
\hline \multicolumn{3}{|l|}{ Exhaled nitric oxide } \\
\hline $\mathrm{F}_{\mathrm{E}} \mathrm{N0}_{0.05}$ (as continuous variable, per $\mathrm{ppb}$ ) & $1.02(1.00$ to 1.03$)$ & 0.061 \\
\hline $\mathrm{C}_{\mathrm{A}} \mathrm{NO}$ (as continuous variable, per ppb) & $1.06(1.03$ to 1.09$)$ & $<0.001$ \\
\hline SSc patients with $\mathrm{C}_{\mathrm{A}} \mathrm{NO}>5.3 \mathrm{ppb}^{*}$ & $6.80(2.84$ to 16.26$)$ & $<0.001$ \\
\hline $\mathrm{J}_{\text {awNO }}$ (as continuous variable, $\mathrm{ml} / \mathrm{min}$ ) & $1.00(0.99$ to 1.01$)$ & 0.762 \\
\hline
\end{tabular}

${ }^{*}$ As categorical variable.

†Proportion of predicted value.

$\mathrm{C}_{\mathrm{A}} \mathrm{NO}$, alveolar concentration of nitric oxide; TLCo, carbon monoxide transfer factor; $\mathrm{F}_{\mathrm{E}} \mathrm{NO}_{0.05}$ fractioned exhaled nitric oxide at $50 \mathrm{ml} / \mathrm{min}$ of outflow; FVC, forced vital capacity; ILD, interstitial lung disease; $J^{\prime}{ }_{\text {awNO}} \mathrm{NO}$, conducting airways nitric oxide output; PAP, pulmonary artery pressure assessed by echocardiogrphy; ppb, parts per billion; SSc, systemic sclerosis. 
obtained in the validation study with $8.5 \mathrm{ppb}(\mathrm{Se}=0.53,95 \% \mathrm{CI}$ 0.27 to 0.79 ; $\mathrm{Sp}=0.85,95 \%$ CI 0.68 to 0.95 ) were also very close to those observed in the studied population ( $\mathrm{Se}=0.56,95 \% \mathrm{CI}$ 0.40 to $0.72 ; \mathrm{Sp}=0.91,95 \%$ CI 0.81 to 0.96 ).

\section{Association between $\mathrm{C}_{\mathrm{A}} \mathrm{NO}, \mathrm{F}_{\mathrm{E}} \mathrm{NO}_{0.05}$ and $\mathrm{J}_{\text {aw }}^{\prime} \mathrm{NO}$ at baseline and subsequent deterioration in lung function or death in patients with SSc}

In an unadjusted Cox model, $\mathrm{C}_{\mathrm{A}} \mathrm{NO}$ had a predictive value for the occurrence of combined events $(p<0.001)$ but $\mathrm{F}_{\mathrm{E} \mathrm{NO}_{0.05}}(\mathrm{p}=0.061)$ and $J^{\prime}$ aw NO $(p=0.762)$ did not (table 2$)$.

In the Cox proportional hazards model adjusted for age, gender, smoking status, form of disease, duration of disease, presence of ILD, FVC, TLCO, presence of PH diagnosed by RHC and immunosuppressive therapy, patients with $\mathrm{C}_{\mathrm{A}} \mathrm{NO}>5.3 \mathrm{ppb}$ had a higher risk of subsequent occurrence of combined events (HR 6.06, 95\% CI 2.36 to 15.53; $\mathrm{p}<0.001$ ). The adjusted HR for subsequent combined event occurrence in patients with $\mathrm{C}_{\mathrm{A}} \mathrm{NO}$ $>8.5 \mathrm{ppb}$ was 3.06 (95\% CI 1.43 to 6.55 ; $\mathrm{p}=0.004$ ).

Although the level of TLCO might in theory affect $\mathrm{C}_{\mathrm{A} N O}$ values, it had a low impact on the ability of $\mathrm{C}_{\mathrm{A}}$ NO to predict lung function deterioration or death related to lung fibrosis. Indeed, $\mathrm{C}_{\mathrm{A}} \mathrm{NO}$ was still an accurate predictive factor for the combined event in both patients with TLCO $<60 \%$ of the predicted value and those with TLCO $\geq 60 \%$ of the predicted value. In patients with SSc with TLCO $<60 \%$ of the predicted value the HR was 17.35 (95\% CI 2.25 to 113.96 ; $p=0.006$ ) compared with 4.06 (95\% CI 1.44 to 11.43 ; $p=0.008$ ) in those with TLCO $\geq 60 \%$ of the predicted value. The difference between patients with TLCO $<60 \%$ and $\geq 60 \%$ of the predicted value was not significantly different $(\mathrm{p}=0.074)$.

Relationship between variation in $\mathbf{C}_{\mathbf{A}}$ No level and change in FVC After adjustment for FVC at baseline, FVC at the follow-up visit was related to $C_{A}$ NO at baseline $(\beta \pm S E-0.022 \pm 0.007, p=0.004)$ but not to its change $\left(\mathrm{C}_{\mathrm{A}} \mathrm{NO}\right.$ at inclusion minus that at the follow-up visit; $\beta \pm S E-0.003 \pm 0.004, p=0.450)$.

\section{DISCUSSION}

In this prospective study which assessed various exhaled $\mathrm{NO}$ parameters, we found that $\mathrm{C}_{\mathrm{A} N \mathrm{~N}}$, a marker of alveolar inflammation, was able to predict subsequent lung function deterioration or death in patients with $\mathrm{SSc}(\mathrm{HR}=6.06)$ with a $\mathrm{C}_{\mathrm{A}} \mathrm{NO}$ cut-off at $5.3 \mathrm{ppb}$. $\mathrm{A} \mathrm{C}_{\mathrm{A}} \mathrm{NO}$ cut-off at $8.5 \mathrm{ppb}$ allowed the identification (with $90 \%$ specificity) of patients at high risk of deteriorating lung function who subsequently developed SSc-related ILD. This prediction power of elevated $\mathrm{C}_{\mathrm{A}}$ NO was then validated in an independent cohort population (figure 3 and 4).

The results of this study are consistent with the hypothesis that alveolar inflammation plays an important role in the progression of pulmonary fibrosis leading to SSc-related ILD. They provide strong evidence linking alveolar inflammation (as reflected by high levels of $\mathrm{C}_{\mathrm{A}} \mathrm{NO}$ ) with losses in lung volumes due to progression of lung fibrosis during the natural course of the disease. Other prediction factors such as chest HRCT and FVC can also accurately detect or assess the extent of lung fibrosis in patients with $\mathrm{SSc}^{2425}$ and have a relevant predictive value. Thus, a subgroup of patients with SSc with a history of progressive lung disease testified by a large area of ILD on HRCT scanning or lung volume restriction were more likely to have progression of lung disease during long-term follow-up. ${ }^{4} 24$ These morphological abnormalities of the lung and impaired pulmonary volumes resulted from initial alveolar inflammation that could not be currently measured by lung HRCT or PFTs. In this study, $\mathrm{C}_{\mathrm{A}} \mathrm{NO}$ added relevant information on the activity of lung disease, irrespective of the presence of ILD or a decreased level of FVC that are currently used as accurate predictive markers in SSc. ${ }^{24}$

Athough increased fractional exhaled $\mathrm{NO}$ is seen in patients with active alveolitis, documented by bronchoalveolar lavage cells count, ${ }^{26}$ and also in those without ILD-SSc, ${ }^{27}$ fractional exhaled NO was related to the severity of scleroderma lung disease. ${ }^{14}$ Assessing the locoregional NO output enables us to measure more precisely deep lung inflammation. Previous crosssectional studies by our group have shown that $\mathrm{C}_{\mathrm{A}} \mathrm{NO}$ is increased in patients with SSc compared with controls ${ }^{14} 28$ and
Figure 3 Kaplan-Meier survival analysis grouped by baseline alveolar concentration of nitric oxide $\left(\mathrm{C}_{\mathrm{A}} \mathrm{NO}\right)$ according to the best cut-off to predict deterioration in lung function or death 3 years after inclusion in the study. The survival curves are from two different populations. The black lines represent patients with systemic sclerosis (SSc) from Saint Antoine Hospital $(n=105)$ and the grey lines represent patients with SSc from Cochin Hospital for external validation $(n=48)$. The continuous lines show the survival curves for patients with $\mathrm{SSc}$ with $\mathrm{C}_{\mathrm{A}} \mathrm{NO}$ $\leq 5.3 \mathrm{ppb}$ and the broken lines represent patients with $\mathrm{SSc}$ with $\mathrm{C}_{\mathrm{A}} \mathrm{NO}$ $>5.3 \mathrm{ppb}$. Patients with $\mathrm{SSc}$ with $\mathrm{C}_{\mathrm{A}} \mathrm{NO}$ $>5.3 \mathrm{ppb}$ were more likely to develop lung function deterioration or death than other patients (log rank, $\mathrm{p}<0.001$ ).

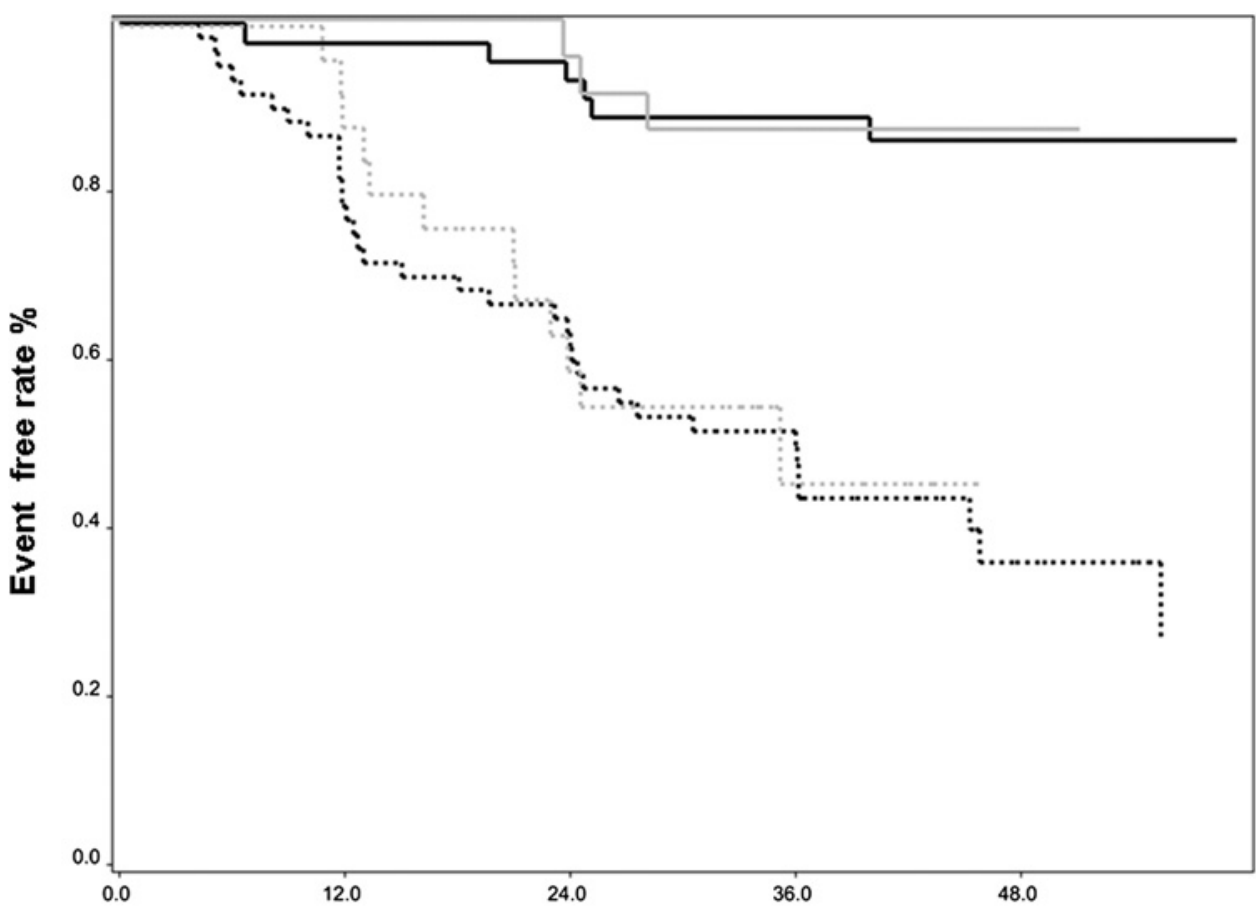

Time (months) 
Figure 4 Exhaled flow rate $\left(\mathrm{V}_{\mathrm{E}}\right)$ and nitric oxide exhaled flow rate $\left(\mathrm{V}_{\mathrm{NO}}\right)$ from patients with systemic sclerosis (SSc). Extended NO analysis may be less accurate in low exhaled flow rate $<50 \mathrm{ml} / \mathrm{s}$ due to axial back diffusion. Eight of 105 patients with SSc had a first $V_{E}$ measurement of $\leq 50 \mathrm{ml} / \mathrm{s}$; the analysis did not affect the prediction concentration of nitric oxide $\left(\mathrm{C}_{A} \mathrm{NO}\right)$ for subsequent lung function deterioration or death (adjusted HR 2.98, $\mathrm{p}=0.0003$ ). Each square represents one exhaled flow rate measurement. Each patient had three or more exhalations against positive different pressures that enabled calculation of $\mathrm{C}_{\mathrm{A}} \mathrm{NO}$ according to the model described by Tsoukias et al. ${ }^{12}$ The triangles represent the mean $V_{E}$ for exhalation against $50 \mathrm{ml} / \mathrm{s}, 100 \mathrm{ml} / \mathrm{s}$ and $150 \mathrm{ml} / \mathrm{s}$; the majority of patients with SSc cannot maintain a stable $V_{E}$ against $200 \mathrm{ml} / \mathrm{s}$. exclusion of these eight patients from power of baseline alveolar

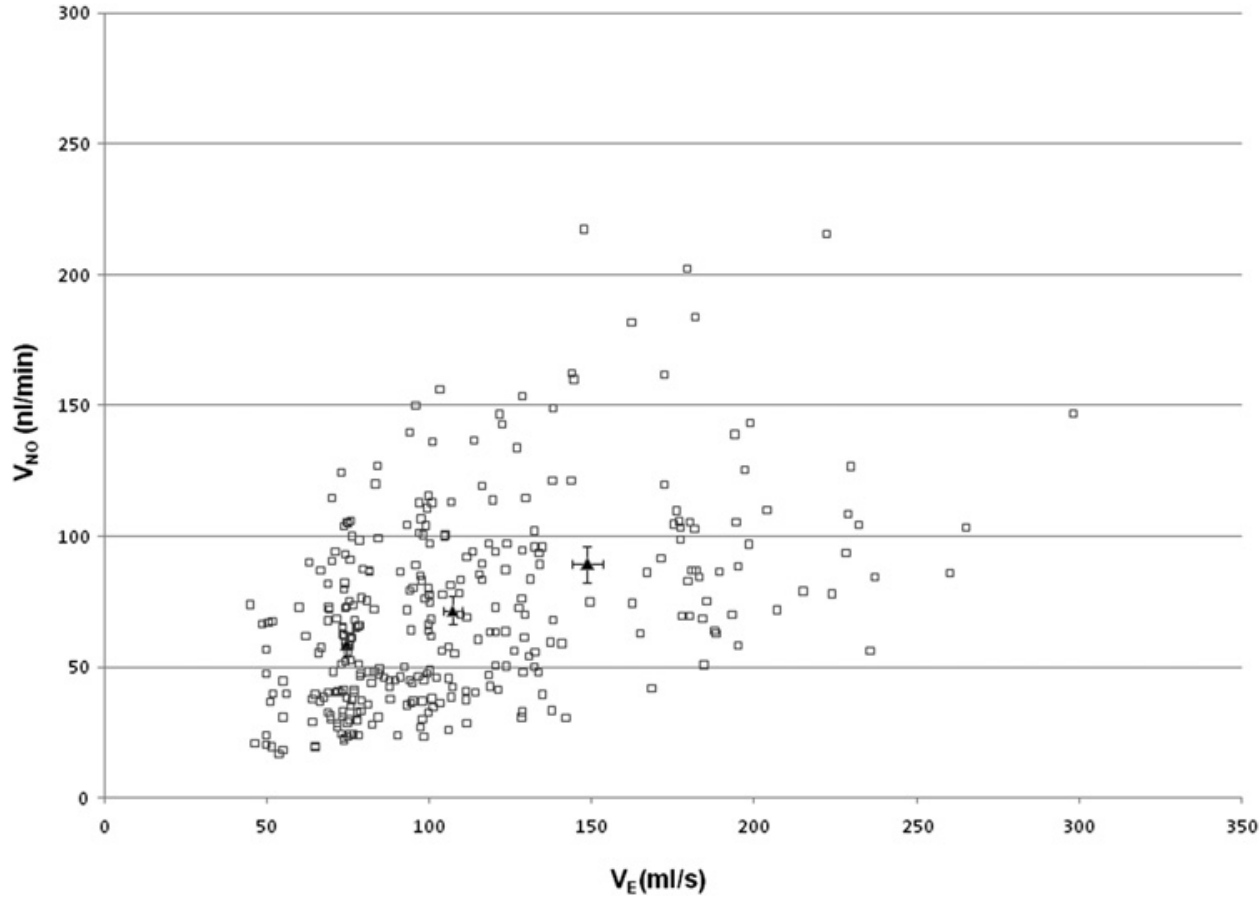

is higher in SSc patients with ILD than in patients without ILD. ${ }^{14}$ Moreover, $\mathrm{C}_{\mathrm{A}} \mathrm{NO}$ is directly related to the presence of ILD on chest HRCT scanning, ${ }^{29}$ probably due to as yet unknown biological mechanisms linking active alveolitis to cell proliferation and lung fibrosis in patients with SSc. ${ }^{15}$

Chest HRCT scanning and FVC are reliable tools for describing radiological abnormalities and lung volumes losses. Conversely, as increased NO synthesis directly results from inflammatory processes, $\mathrm{C}_{\mathrm{A}} \mathrm{NO}$ can accurately and specifically sense the presence of lung inflammation and quantify its importance, irrespective of the presence of lung fibrosis and its severity. It is therefore conceivable that high levels of $\mathrm{C}_{\mathrm{A}} \mathrm{NO}$ occur in some patients with lung inflammation but without ILD-for example, during the early course of their disease. Conversely, a patient with a long history of ILD can have normal levels of $\mathrm{C}_{\mathrm{A}} \mathrm{NO}$ during a quiescent phase of the disease when inflammatory processes are controlled or absent.

In this study the rate of progression in our patients was consistent with that reported in previous large cohort studies. ${ }^{4}$ The greater power of $\mathrm{C}_{\mathrm{A}} \mathrm{NO}$ to predict deteriorating lung func-

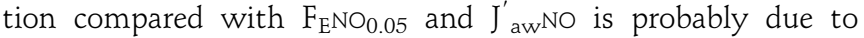
the fact that alveolar inflammation (as measured by $\mathrm{C}_{\mathrm{A} N \mathrm{~N}}$ ) rather than inflammation of the proximal airways (as measured by $\mathrm{F}_{\mathrm{ENO}_{0.05}}$ and $\mathrm{J}^{\prime}{ }_{\mathrm{aw}} \mathrm{NO}$ ), ${ }^{30}{ }^{31}$ plays an important role in the pathogenesis of pulmonary fibrosis in patients with SSc.

The optimal threshold of $\mathrm{C}_{\mathrm{A} N O}$ allows us to demonstrate the relevance and the validation of $\mathrm{C}_{\mathrm{A}} \mathrm{NO}$ as an accurate predictor of subsequent deterioration in lung function or death in the course of SSc. The threshold of $\mathrm{C}_{\mathrm{A} N O}$, presently set at $8.5 \mathrm{ppb}$, might be useful to initiate treatments to prevent lung volume loss in future randomised clinical trials or to treat alveolar inflammation in the hope of delaying the development of lung fibrosis. We have previously reported in cross-sectional studies that high $\mathrm{C}_{\mathrm{ANO}}$ levels were associated with the presence of ILD on lung HRCT scans or the ability of the serum to induce myofibroblast transition. ${ }^{14} 2829$ Indeed, ILD can be ruled out in patients with $\mathrm{C}_{\mathrm{ANO}}<3.8 \mathrm{ppb}^{29}$ and increased $\mathrm{C}_{\mathrm{ANO}}$ is associated with a severe form of ILD in SSc. ${ }^{14}$ Moreover, the serum from patients with $\mathrm{C}_{\mathrm{A}} \mathrm{NO}>4.3 \mathrm{ppb}$ was able to induce lung fibroblast proliferation and myofibroblast conversion. ${ }^{15}$ These cut-offs were still relevant and added functional information on scleroderma lung disease at the time extended $\mathrm{NO}$ analysis was performed. In contrast to these previous thresholds, the present prospective cohort study reinforces the clinical usefulness of this measurement as $\mathrm{C}_{\mathrm{A}}$ NO levels $>8.5 \mathrm{ppb}$ are strongly associated with the subsequent risk of lung function deterioration or death. External validation in an independent cohort of patients with SSc further reinforced the validity of this cut-off value.

In conclusion, our findings show that increased $\mathrm{C}_{\mathrm{A}} \mathrm{NO}$ is a noninvasive and valuable means of identifying patients with SSc at high risk of developing subsequent lung function deterioration or death, irrespective of the FVC level and the presence of ILD. This should allow clinicians to follow closely patients with progressive form and to initiate appropriate treatments in an early phase of disease.

\section{Competing interests None.}

Patient consent Obtained.

Ethics approval Ethics approval was provided by CPP lle de France.

Contributors KPT, TH-H, AK, YA, N-NL-D, SD-Q, JC and ATD-X were responsible for data collection, data interpretation and preparation of the report. KPT and AK were responsible for data analysis. All authors contributed to critical revision of the report.

Provenance and peer review Not commissioned; externally peer reviewed.

\section{REFERENCES}

1. Gabrielli A, Avvedimento EV, Krieg T. Scleroderma. N Engl J Med 2009;360:1989-2003.

2. Steen VD, Conte C, Owens GR, et al. Severe restrictive lung disease in systemic sclerosis. Arthritis Rheum 1994:37:1283-9.

3. Steen VD, Medsger TA. Changes in causes of death in systemic sclerosis, 1972-2002. Ann Rheum Dis 2007;66:940-4.

4. Assassi S, Sharif R, Lasky RE, et al; GENISOS Study Group. Predictors of interstitial lung disease in early systemic sclerosis: a prospective longitudinal study of the GENISOS cohort. Arthritis Res Ther 2010:12:R166.

5. Wells AU, Behr J, Silver R. Outcome measures in the lung. Rheumatology 2008; 47:v48-50.

6. Harrison NK, Myers AR, Corrin B, et al. Structural features of interstitial lung disease in systemic sclerosis. Am Rev Respir Dis 1991;144:706-13.

7. Tashkin DP, Elashoff R, Clements PJ, et al; Scleroderma Lung Study Research Group. Cyclophosphamide versus placebo in scleroderma lung disease. N Engl J Med 2006;354:2655-66. 
8. Tashkin DP, Elashoff R, Clements PJ, et al: Scleroderma Lung Study Research Group. Effects of 1-year treatment with cyclophosphamide on outcomes at 2 years in scleroderma lung disease. Am J Respir Crit Care Med 2007;176:1026-34.

9. Thannickal VJ, Toews GB, White ES, et al. Mechanisms of pulmonary fibrosis. Ann Rev Med 2004;55:395-417.

10. Ricciardolo FL, Sterk PJ, Gaston B, et al. Nitric oxide in health and disease of the respiratory system. Physiol Rev 2004;84:731-65.

11. Fajac I, Kahan A, Menkes CJ, et al. Increased nitric oxide in exhaled air in patients with systemic sclerosis. Clin Exp Rheumatol 1998:16:547-52.

12. Tsoukias NM, George SC. A two-compartment model of pulmonary nitric oxide exchange dynamics. J Appl Physiol 1998;85:653-66.

13. Girgis RE, Gugnani MK, Abrams J, et al. Partitioning of alveolar and conducting airway nitric oxide in scleroderma lung disease. Am J Respir Crit Care Med 2002;165:1587-91.

14. Tiev KP, Cabane J, Aubourg F, et al. Severity of scleroderma lung disease is related to alveolar concentration of nitric oxide. Eur Respir J 2007:30:26-30.

15. Hua-Huy T, Tiev KP, Chereau C, et al. Increased alveolar concentration of nitric oxide is related to serum-induced lung fibroblast proliferation in patients with systemic sclerosis. J Rheumatol 2010;37:1680-7.

16. Preliminary criteria for the classification of systemic sclerosis (scleroderma) Subcommittee for scleroderma criteria of the American Rheumatism Association Diagnostic and Therapeutic Criteria Committee. Arthritis Rheum 1980;23:581-90.

17. LeRoy EC, Black C, Fleischmajer R, et al. Scleroderma (systemic sclerosis): classification, subsets and pathogenesis. J Rheumatol 1988;15:202-5.

18. Miller MR, Hankinson J, Brusasco V, et al; ATS/ERS Task Force. Standardisation of spirometry. Eur Respir J 2005;26:319-38.

19. American Thoracic Society, European Respiratory Society. American Thoracic Society/European Respiratory Society International Multidisciplinary Consensus Classification of the Idiopathic Interstitial Pneumonias. This joint statement of the American Thoracic Society (ATS), and the European Respiratory Society (ERS) was adopted by the ATS board of directors, June 2001 and by the ERS Executive Committee, June 2001. Am J Respir Crit Care Med 2002:165:277-304.

20. McLaughlin VV, Archer SL, Badesch DB, et al. ACCF/AHA. ACCF/AHA 2009 expert consensus document on pulmonary hypertension: a report of the American College of
Cardiology Foundation Task Force on Expert Consensus Documents and the American Heart Association: developed in collaboration with the American College of Chest Physicians, American Thoracic Society, Inc., and the Pulmonary Hypertension Association. Circulation 2009:119:2250-94.

21. American Thoracic Society, European Respiratory Society. ATS/ERS recommendations for standardized procedures for the online and offline measurement of exhaled lower respiratory nitric oxide and nasal nitric oxide, 2005. Am J Respir Crit Care Med 2005;171:912-30.

22. George SC, Hogman M, Permutt S, et al. Modeling pulmonary nitric oxide exchange. J Appl Physiol 2004;96:831-9.

23. DeLong ER, DeLong DM, Clarke-Pearson DL. Comparing the areas under two or more correlated receiver operating characteristic curves: a nonparametric approach. Biometrics 1988;44:837-45

24. Goh NS, Desai SR, Veeraraghavan S, et al. Interstitial lung disease in systemic sclerosis: a simple staging system. Am J Respir Crit Care Med 2008:177:1248-54.

25. Bouros D, Wells AU, Nicholson AG, et al. Histopathologic subsets of fibrosing alveolitis in patients with systemic sclerosis and their relationship to outcome. Am J Respir Crit Care Med 2002;165:1581-6.

26. Paredi $\mathbf{P}$, Kharitonov SA, Loukides $\mathrm{S}$, et al. Exhaled nitric oxide is increased in active fibrosing alveolitis. Chest 1999:115:1352-6.

27. Moodley YP, Lalloo UG. Exhaled nitric oxide is elevated in patients with progressive systemic sclerosis without interstitial lung disease. Chest 2001;119:1449-54.

28. Tiev KP, Le-Dong NN, Duong-Quy S, et al. Exhaled nitric oxide, but not serum nitrite and nitrate, is a marker of interstitial lung disease in systemic sclerosis. Nitric Oxide 2009;20:200-6.

29. Tiev KP, Coste J, Ziani M, et al. Diagnostic value of exhaled nitric oxide to detect interstitial lung disease in systemic sclerosis. Sarcoidosis Vasc Diffuse Lung Dis 2009;26:32-8.

30. Smith AD, Cowan JO, Brassett KP, et al. Use of exhaled nitric oxide measurements to guide treatment in chronic asthma. N Engl J Med 2005;352:2163-73.

31. Lehtimäki L, Kankaanranta $H$, Saarelainen $S$, et al. Extended exhaled NO measurement differentiates between alveolar and bronchial inflammation. Am J Respir Crit Care Med 2001:163:1557-61.

\section{Journal club}

\section{Lectin-mediated innate defences are important in limiting disease in influenza}

The innate immune system is an important defence against previously unencountered pathogens. It recognises surface glycans through cell-associated and soluble lectin-mediated defences. This study investigates the effect of blocking these defences on antiviral activities and disease severity in influenza infection.

Mice were infected with two influenza viruses that differ in the degree of glycosylation of the surface glycoprotein haemagluttinin. Infection with the poorly glycosylated H1N1 virus PR8 resulted in rapid weight loss and a 100\% 5-day mortality, whereas the highly glycosylated PR8 reassortant BJx109 resulted in no significant weight loss and a 0\% 10-day mortality. This result was replicated in knockout mice with impaired $\mathrm{B}$ and $\mathrm{T}$ cell function demonstrating that the innate immune system was sufficient to limit disease.

In vitro only the highly glycosylated BJx109 (H3N2) virus infected airway macrophages to high levels and was neutralised by mouse bronchoalveolar lavage and a soluble lectin present in respiratory secretions. These antiviral activities were blocked through preincubation with the polysaccharide mannan indicating that they are lectin mediated. In vivo, blocking these lectin-mediated defences with intranasal mannan led to increased clinical disease as measured by weight loss and 10-day mortality and increased pathological airway disease as measured by virus titres, immunopathology scoring and bronchoalveolar lavage protein levels. Mannan treatment had no effect on antiviral activities or disease severity in PR8 virus infection.

This study demonstrates that surface glycosylation affects the ability of a virus to evade innate lectin-mediated defences, contributing to the degree of clinical and pathological disease caused.

Tate M, Brooks G, Reading P. Inhibition of lectin-mediated innate host defences in vivo modulates disease severity during influenza virus infection. Immunol Cell Biol 2011;89:482-91.

\section{Neelam Kumar}

Correspondence to Dr N Kumar, Clinical Infection Unit, St George's Hospital, Blackshaw Road, Tooting, London SW17 00T, UK; neelamkumar@doctors.org.uk

Published Online First 6 May 2011

Thorax 2012;67:163. doi:10.1136/thoraxjnl-2011-200358 